\title{
Production Shifts and Upgrading in ASEAN Automotive Production Network: Case on Toyota-led Regional Value Chains
}

\author{
Riza Noer Arfani ${ }^{1}$ \\ Awan Setya Dewanta ${ }^{2}$
}

\begin{abstract}
The study aims at exploring the phenomenon of regional production network in ASEAN (Association of Southeast Asian Nations) automotive sector/industry by employing a firm as well as macro-level analysis of data gathered through combining techniques between deskstudy and a series of fieldwork. It examines patterns of production and manufacturing activities of leading Japanese automotive firms and their upgrading strategies as showcased by Toyota in an endeavor to cast the much-aspired ASEAN Regional Value Chains (RVCS). Production shifts have been apparent as indicated in the trade patterns and trends in value added of key automotive products traded between Japan and its ASEAN partners during the past 25 years. The shifts have resulted in deepened localization of production and manufacturing activities of Japanese automotive lead firms in ASEAN countries. Such dynamic shifts, as shown especially in passenger cars and automotive parts and accessories, have further prompted upgrading efforts by the lead firms (along with their suppliers, subsidiaries, and local partners) which suggest the functioning RVCs. The upgrading embraces areas of upstream (on research, development, and design or RD\&D), midstream (on production, manufacturing, and assembly) as well as downstream (on sales, marketing, and after-market) activities. Future policy outlook lays on the ability of firms and other related stakeholders in the region's automotive sector/industry to team up in the upgrading activities and hence capture the valueadded. ASEAN-Japan long and strong historical relations facilitate the enhanced collaborative automotive industrial development, particularly in the areas of technical capacity formation and supporting industries.
\end{abstract}

Keywords: Regional Value Chains, Production Shifts, Upgrading, ASEAN Automotive Production Network

\footnotetext{
${ }^{1}$ Lecturer at the Department of International Relations, Faculty of Social and Political Sciences, Universitas Gadjah Mada, (UGM) Yogyakarta, Indonesia; Researcher at the Center for World Trade Studies (CWTS) UGM; and Chair of the WTO Chairs Programme (WCP) Indonesia/UGM. The article is part of the $1^{\text {st }}$ author's doctoral research work on "Regional Value Chains and the Japanese Automotive Production Network in Southeast Asia" at the Graduate School of International Relations (GSIR), Ritsumeikan University, Kyoto, Japan. The authors would like therefore to convey a sincere gratitude to Professor Hideaki OHTA (the $1^{\text {st }}$ author chief dissertation adviser) for his full support of this research, insightful inputs and comments, and shared research resources and networks. Portions of funding of the works (i.e. the doctoral program scholarship and fieldwork activity) are provided under the BPPLN DIKTI (Government of Indonesia's Ministry of Research, Technology dan Higher Education, Directorate General of Resources for Science, Technology and Higher Education) Scholarship Scheme and Ritsumeikan University's Kokusaiteki Research Fund. Corresponding e-mail: rnarfani@ugm.ac.id

2 Lecturer at the Faculty of Economics, Universitas Islam Indonesia (UII), Yogyakarta, Indonesia.
} 


\section{Introduction}

The expansion of production networks in ASEAN manufacturing sectors is embedded in the operations of global firms, their local affiliates and partners, and suppliers within their regional production and supply chains. As early as the 1970s, companies (particularly in the textile and clothing [T\&C] and electronics and electrical [E\&E] industries) began to shift production out of the United States and other developed countries and tap in four key countries: Indonesia, Malaysia, the Philippines, and Thailand (Kuroiwa \& Heng, 2008). The T\&C and E\&E sectors were followed by the automotive sector in the 1990s when several leading companies (mostly from Japan) decided to move their manufacturing facilities to the region in light of the 1988 ASEAN "brand to brand complementation" (BBC) agreement and the anticipated lowering of costs of auto assembly/production due to more efficient supply chains, logistics, delivery, and procurement.

Toyota Motor Corporation (TMC) was one of the Japanese automotive companies that initiated such a strategic move. At the end of 1990s, TMC began to utilise its manufacturing plants in Thailand as a production hub serving local, regional and global markets through its IMV (Innovative International Multipurpose Vehicle) Project, despite the ongoing effects of the 1997-98 Asian monetary crisis. The move resulted in locally designed and manufactured vehicles, i.e. one-ton Pickup trucks in Thailand and small multipurpose vehicles (MPVs) in Indonesia by the year of 2004 (TMC 1, 2017). These vehicle types are based on Toyota's ASEAN IMV platform, which has become a key part of the Toyota New Global Architecture (TNGA) strategy (Takeno, 2017).

ASEAN scholars and members of policy circles alike have had particular concern for how integrated production networks (as exemplified here by TMC) at certain points foster regional economic integration (ASEAN Secretariat and World Bank, 2015). More specifically, this is a question of how firms engage in activities that reinforce the regional economic integration scheme envisaged under the ASEAN Economic Community (AEC). ${ }^{\mathrm{i}}$ As suggested in this paper, it is a question on how this engagement has been driven by firms' upgrading efforts as a result of increased localisation of production/manufacturing activities. This particular question is addressed here by exploring the historical engagement of TMC and its operations in its ASEAN automotive production network. 
In addition to a case study of TMC, this research employs both macro and micro analytical methods. At the macro level, trade patterns and trends in Japanese and ASEAN automotive products are presented through statistical data analysis using the UN Comtrade Database (i.e. on products categorised HS 87-motor vehicles other than railway and tramway) and the OECD-WTO Trade in Value Added (TiVA) Database (i.e. on products categorised SITC C34T35-transport equipment). At the micro level, exploration and assessment of production shifts and companies' upgrading strategies are presented by focusing on TMC operations in key ASEAN countries (i.e. Indonesia, Malaysia, the Philippines, Singapore, Thailand, and Vietnam).

Previous works examining automotive regional production networks (particularly in East Asia and ASEAN) have emphasised the mechanics, organisational structures, and factors behind expansion (Kimura, 2007; Kuroiwa \& Heng, 2008; Ando \& Kimura, 2009; Soejachmoen, 2016). In line with major works on global production networks (GPN) and global value chains (GVC), those works share a common understanding that product fragmentation has led to the vertical integration of production and manufacturing activities.

As in GPN and GVC conceptualisation and theorisation (such as that offered by Gereffi, 1995; Humphrey \& Schmitz, 2000), a regional production network operates within a regional value chain, as in the case of the ASEAN automotive industry, in which Japanese companies, their subsidiaries, local partners, and suppliers network play a leading role in business and production expansion. Observed from an international relations and/or international political economy perspective, regional production networks and value chains (RPNs and RVCs) play an important part in overall regional economic integration due to their integrative nature.

This paper intends, hence, to investigate the role of ASEAN automotive RPNs and RVCs (most of which involve leading Japanese original equipment manufacturers [OEMs]) in fostering regional economic integration. The case of TMC, as well as the production shifts and upgrading resulting from its increased localisation of production, is a notable one among Japanese automotive OEMs. As such, Toyota-led RVCs are presented to showcase measures taken by TMC (and other OEMs) that reflect accumulating processes of localised production and regional supply chains. The processes span across value chains and are undertaken through a combination of direct foreign investment (both green and brownfield) for production facility 
expansion and maintenance, enhanced regional procurement and supply chains, locally developed RD\&D (research, development, and design) centres, and reinforced subsidiaries and local partnerships.

To date, TMC's production strategies have predominantly featured a basic, generic, and general understanding of the company's renowned Toyota Production System (TPS), including Ohno's classic Toyota seisan hoshiki (1978). This work was soon followed by scholars such as Cusumano (1985), who compares Toyota and Nissan's production systems; Womack, Jones and Roos (1990) who equates and explores TPS as a lean production; Monden (2012), who gives a detailed description of TPS as a just-in-time (JIT) production process; Liker (2004) and Liker and Hoseus (2008), who illuminate the Toyota Way and TPS' derivative management concepts and practices. Such a basic understanding offers a conceptual framework for the actual operations of Toyota-led RVCs, which in turn is essential for assessing the contributions of TMC and other automotive OEMs in regional economic integration.

The next part of this paper (Findings and Discussion) presents the major results of my research and is outlined as follows. To present the general setting of TMC and other Japanese OEMs' operations through their regional production networks in Southeast Asia, the first section offers a review of patterns and trends in the trade of automotive products between Japan and ASEAN, with specific reference to two key automotive products: passenger cars (HS 8703) and auto parts and accessories (HS 8708). The second section showcases TMC's involvement in the ASEAN automotive production network, i.e. its structural organisation/spatial linkages, upgrading, and value chains. It describes TMC's position and role as a leading automotive company, as well as how the firm links to its first-tier suppliers, local partners and subsidiaries, as well as other related stakeholders. The third section elaborates on Toyota-led value chains in ASEAN and the transfer of products, parts, and components within TMC's production network. Elucidation of TMC production shifts in ASEAN is aimed at examining the company's upgrading efforts as it deepens localisation of production and accumulation of localised technical capacity and knowledge transfers. 


\section{Research Findings}

As indicated earlier, the key findings of the study are presented and discussed in three sections, focusing on: (1) Trade Setting (in the trade of automotive products between Japan and ASEAN, with a focus on HS 87 and SITC C34T35); (2) Showcasing TMC's involvement in ASEAN automotive production networks; (3) Toyota Value Chains (for production shifts and upgrading).

\section{Trade Setting}

In 2016, Japan's trade of products under HS 87 (motor vehicles other than railway and tramway) with its key ASEAN partners (hereafter ASEAN6, consisting of Indonesia, Malaysia, the Philippines, Singapore, Thailand, and Vietnam) represents USD 13.16 billion or $7.2 \%$ of its total trade with ASEAN6 (of USD 182.2 billions). The total value of its exports to ASEAN6 in products under HS 87 is USD 10.76 billion, while its imports are valued at USD 2.39 billion, resulting in a surplus of USD 8.37 billion. Thailand is Japan's most important partner in its HS 87 trade with a total value worth of USD 4.3 billion (about $2.3 \%$ of the total value Japan-ASEAN6 trade) as of 2016. Indonesia, the Philippines, and Malaysia come next, with total trade values of USD 2.2 billion, USD 2 billion, and USD 1.89 billion as of 2016 respectively. Singapore and Vietnam, meanwhile, respectively account for total values of USD 1.41 billion and USD 1.36 billion as of 2016 (UN Comtrade, 2017).

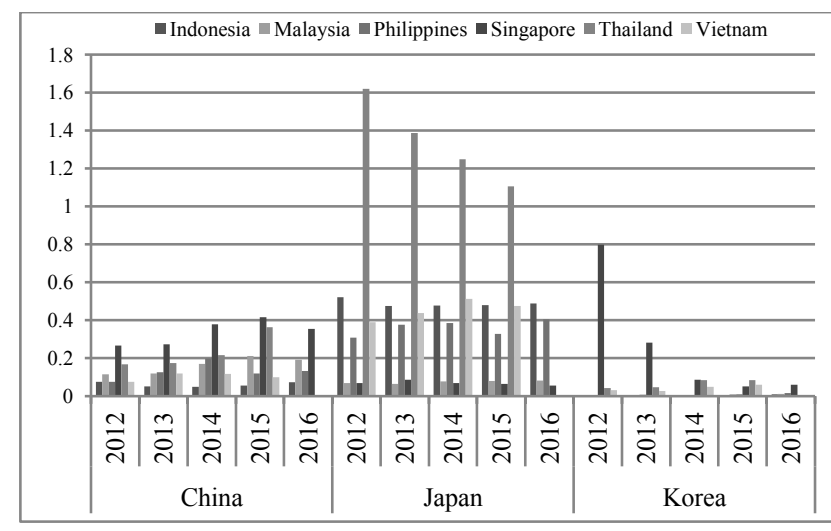

Exports 


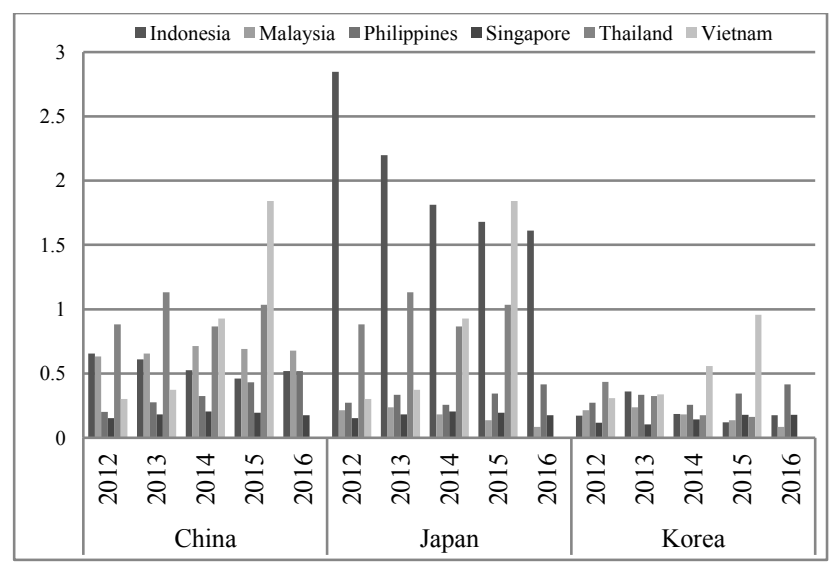

Imports

Diagram 1. ASEAN6 Exports to and Imports from East Asian Countries, HS 87

Products (USD billions, 2012-2016)

(Source: UN Comtrade Database, 2017)

Note: 2016 data for Thailand and Vietnam are not available

Compared to its closest competitors in the region (i.e. China and Korea), Japan has become dominant in the ASEAN6 trade in HS 87 products. The following diagrams reveal that this has occurred over the past five years (2012-2016) despite the emergence of China as a major origin of HS 87 imports, particularly to Singapore and Vietnam. Despite its position having weakened since 2012, Thailand remains the leading exporter of HS 87 products to Japan (as shown in Diagram 1) and Indonesia remains the leading importer of HS 87 products from Japan (as shown in Diagram 2).

Since the end of the 1980s, i.e. for more than 25 years, ASEAN countries' trade with Japan in HS 87 products has been characterised by ebbs and flows. As shown in Diagram 2, showing Japan's trade with the two leading ASEAN countries (i.e. Thailand and Indonesia), Japan experienced its first boom exports in 1995 (with exports to Thailand reaching a record USD 3.7 billion), though this soon burst as the 1997 Asian monetary crises hit the two countries. In its aftermath, however, the uptrend returned promptly. It started gaining momentum in 2004 and peaked once again in 2012, despite a brief downturn in 2009 as a result of the 2008 global financial crisis. 
Products (USD millions, 1988-2016)

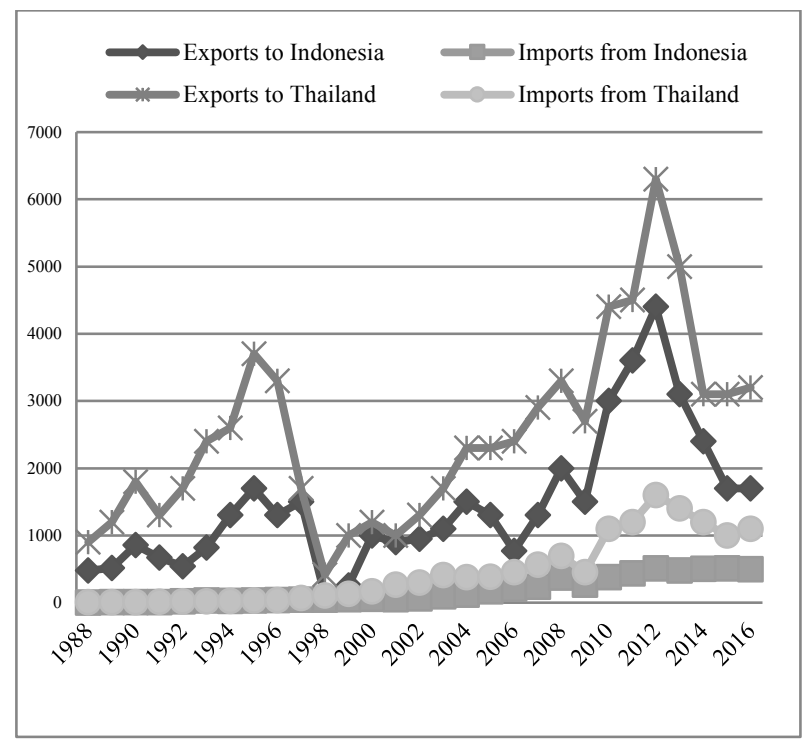

Diagram 2. Japan's Exports to and Imports from Thailand and Indonesia, HS 87 (Source: UN Comtrade Database, 2017)

Breaking down the HS 87 trade between Japan and these two countries (i.e. Thailand and Indonesia), with main imported products being motor vehicle parts and accessories (HS 8708) and the main exported products primarily being passenger cars (HS 8703). In HS 8708 trade, Thailand was Japan's third partner in 2014 capturing $8 \%$ of the country's total export value of HS 8708 products (USD 31.8 billion) and $9 \%$ of its total import value of products in the same category (USD 7.08 billion). Meanwhile, for HS 8703 products, Thailand captured 3\% of Japan's total import value as of 2014, while Indonesia took 4\% of both Japan's total HS 8708 exports and imports (as of 2014). Other ASEAN countries with significant share in Japan's HS 8708 exports and imports are Singapore, Vietnam, and the Philippines. Singapore took 1\% of Japan's total HS 8708 exports, and Vietnam took 4\% of Japan's total HS 8708 imports (as of 2014) (UN Comtrade Database, 2017).

Since 1988, in terms of value, Japan's HS 8703 (passenger cars) trade with Indonesia, Thailand, and Malaysia is about a quarter of that of HS 8708 (parts and accessories) trade. In 2012, Japan's export of passenger cars to Malaysia peaked at USD 1.2 billion, while its parts and accessories exports reached a value of more than USD 4 billion. This indicates that Japan's automotive trade with these three ASEAN countries has been much less dependent on automobile exports and shifted to trade in automobile parts and accessories, confirming significant production shifts in 
Japanese automotive companies' intra-industry trade and regional production networks.

In single-year data from 2012, 2005 and 1993 (i.e. when Japan trade performance with those three ASEAN countries peaked), it is observed that Japan's automobile exports have relied on HS 870323 (vehicles with spark-ignition internal combustion reciprocating piston engines and cylinder capacity of over $1500 \mathrm{cc}$ but not over $3000 \mathrm{cc}$ ). Such medium to large-size automobiles are the most frequently exported to Malaysia (2005 and 2012) and Thailand (1993). Nevertheless, trade value from the import of gasoline (under $1000 \mathrm{cc}$ ) automobiles from Thailand has grown significantly, reaching USD 200 million in 2012 - a sharp increase from its value of less than USD 14,000 in 1993. This indicates the growing significance of small-type cars in Japan-ASEAN automotive trade.

Diagram 3 illustrates the shifting patterns in Japan's trade with Indonesia, Malaysia, and Thailand in passenger cars.

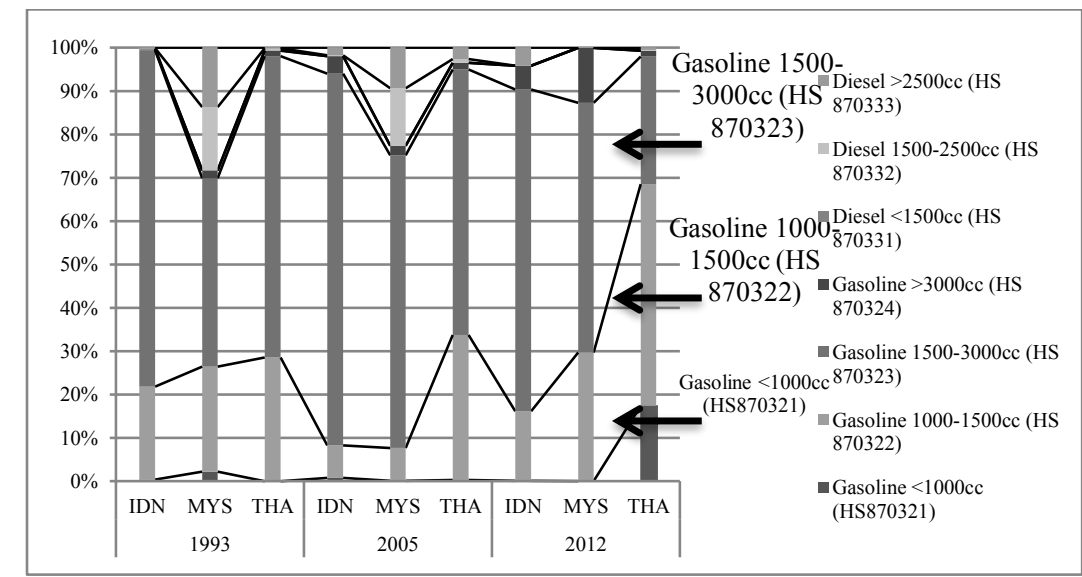

Diagram 3. Shifting Patterns in Passenger Cars Trade between Japan and Selected ASEAN Countries (\% of Total Trade Value for HS 8703 in Each ASEAN Country, 1993, 2005 and 2012)

(Source: UN Comtrade Database, 2017)

This reveals each product category's share in the total Japan HS 8703 trade value in three ASEAN countries. As shown above, trade has shifted generally towards cars with smaller engine capacity. In Indonesia and Malaysia, trade has shifted towards gasoline automobiles of 1000-1500 cc (HS 870322), whereas in Thailand the growing importance of gasoline-type automobiles under 1000 cc has been apparent since 2012 . 
In terms of value-added trade, Japan and its major regional partners have shared dynamic trends for products traded under SITC C34T35 (transport equipment). The following two diagrams (Diagram 5 and 6) visualise the trends by utilising the OECD-WTO TIVA indicators of the foreign final demand domestic value added (FFD-DVA) and domestic final demand-foreign value added (DFD-FVA). FFDDVA value indicates forward trends in trade (i.e. a country's domestic value-added exports going into exports of other countries), whereas DFD-FVA suggests backward trade linkages (i.e. foreign value added in gross exports) (Banga, 2013). Diagram 4 and 5 present trends in FFD-DVA and DFD-FVA, respectively, in Japan's trade of SITC C34T35 products with selected key partners in the region.

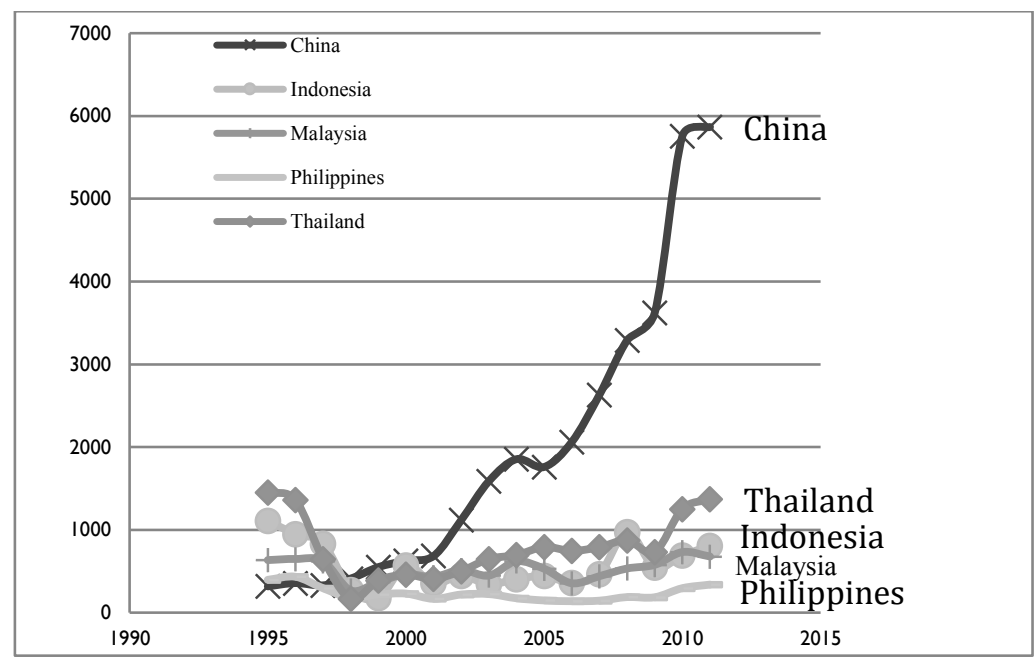

Diagram 4. Japan's FFD-DVA in SITC C34T35 Trade with Selected Regional Partners (USD millions, 1995-2011)

(Source: OECD-WTO TiVA Database, 2017)

Despite having much lower value compared to that created with China, Japan's FFD-DVA in its trade with several key ASEAN countries (Thailand, Indonesia, Malaysia and Philippines) -as shown in Diagram 4-has experienced an upward trend since its sharp decline in 1998; in 2011, Japan's FFD-DVA in its trade with Thailand and Indonesia caught up to 1994 levels. This indicates that the export activities and values of Japanese automotive companies operating in these two key ASEAN countries have returned to regular capacity. Japan has captured less DFDFVA value than its FFD-DVA value, which suggests that the production shifts of most of its lead companies' manufacturing facilities to the region have developed towards a full automotive production hub, particularly in Thailand (and later Indonesia). On 
average, Japan's FFD-DVA value is about a third of its DFD-FVA value.

Diagram 5 below illustrates trends in Japan's DFD-FVA value created in trade with selected partners in the region. China-not shown in the diagram-are reached USD 2,286.4 million (2011) and USD 1,183.6 million (2006). Similar to Japan's DFDFVA with China, the country's trade with ASEAN countries created about one third of its FFD-DVA value on average over time (1995-2011). This particular trend (where the FFD-DVA value is higher than its DFD-FVA) suggests that the value captured by Japanese trade in the region (for SITC C34T35 products) has originated mostly from Japanese OEMs activities and their operating networks in the host countries.

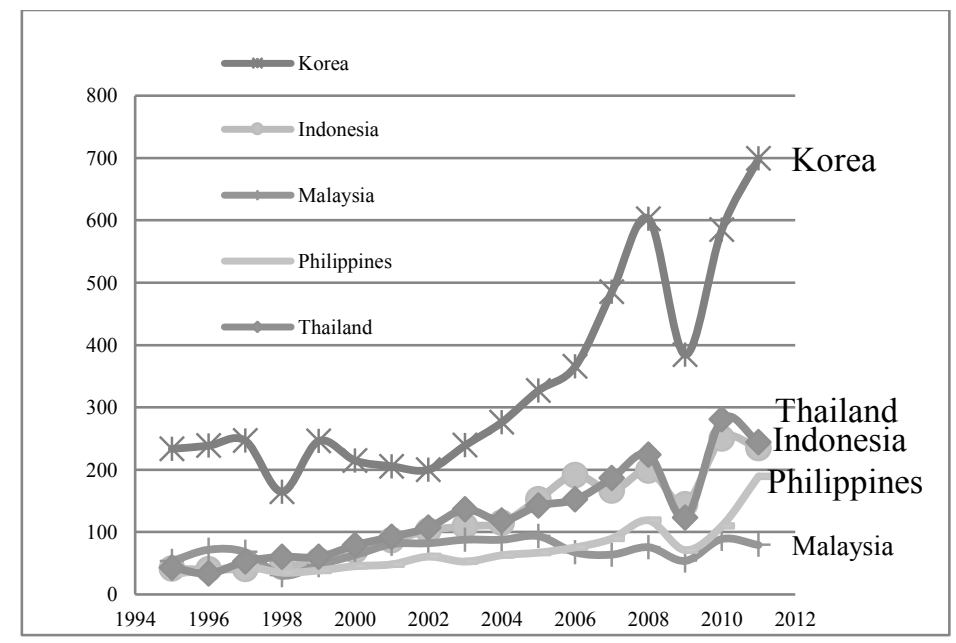

Diagram 5. Japan's DFD-FVA in SITC C34T35 Trade with Selected Regional Partners (USD millions, 1995-2011)

(Source: OECD-WTO TiVA Database, 2017)

As of 2011, Japan's trade with four selected ASEAN partners has created an FFD-DVA value of USD 1,399.9 million (for Thailand), USD 807.1 million (for Indonesia), USD 678 million (for Malaysia) and USD 338.9 million (for the Philippines). This is about five times higher than Japan's DFD-FVA trade values with the same countries, indicating that value-added creation in Japan's automotive trade with ASEAN countries is most likely to occur locally (as a result of localised production and manufacturing activity) than internationally (as part of export/import activities). This phenomenon reflects stronger backward linkages than forward linkages in Japan's trade with ASEAN in automotive products. The next two sections are therefore intended to elucidate the phenomenon using micro-level analysis and a company-level case study of Toyota. 


\section{Showcasing TMC}

As a firm leading a production network, TMC maintains the following structure: the lead company (TMC), first tier suppliers (mostly based in Japan, with affiliates in local host countries), local partners (mostly joint ventures with local companies) and subsidiaries or affiliates in host countries, lower-tier suppliers (mostly in host countries), and local and home country supporting industries:
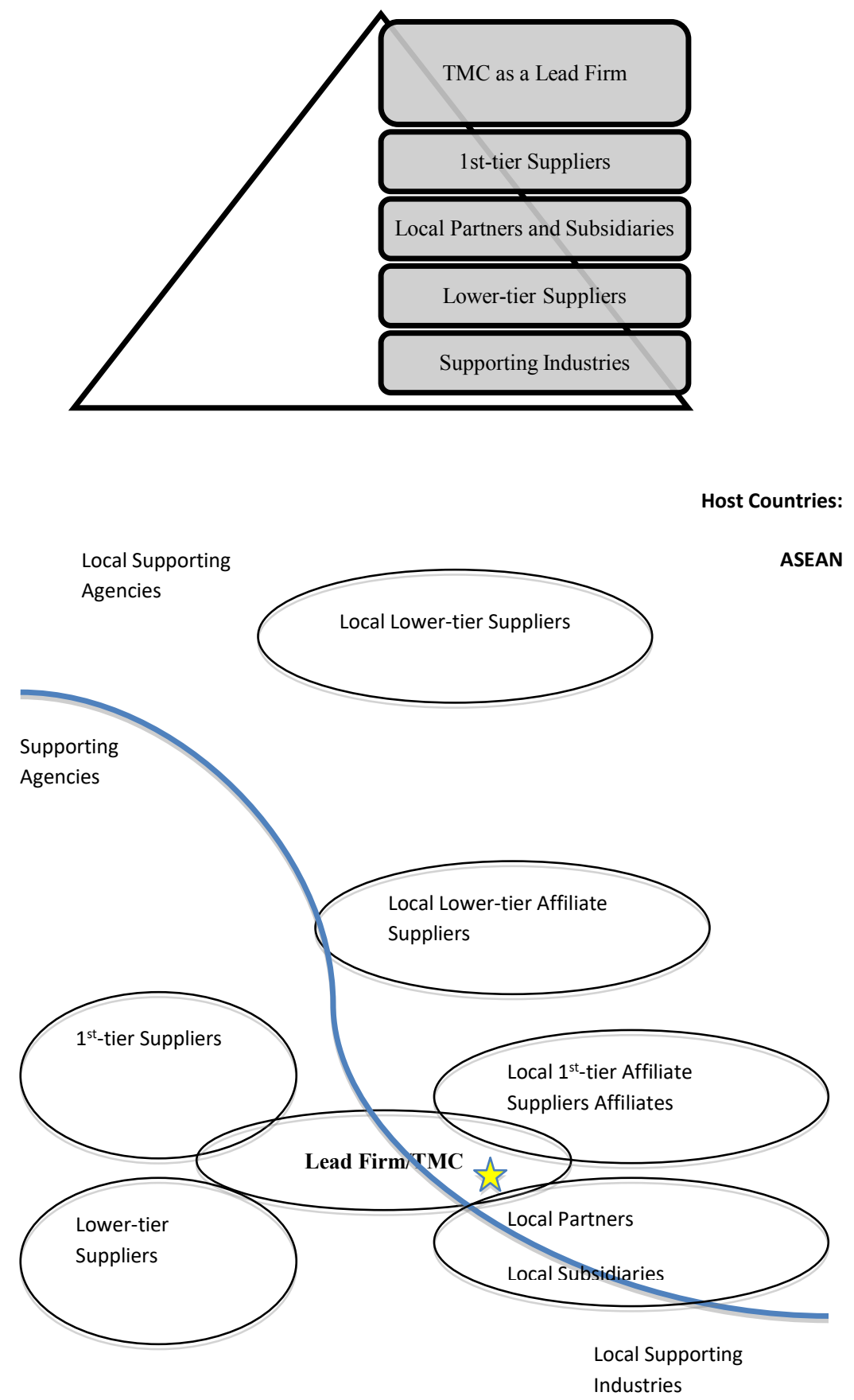

Home Country: Japan

Supporting Industries 
Notes and remarks: (1) as a leading company, TMC is a global company consisting of automotive and non-automotive companies, mainly based in Toyota City (Aichi), Tokyo, and Osaka in Japan; (2) First tier suppliers consist of companies (members of Toyota Group and non-members) directly supplying auto parts and components to TMC; (3) In Southeast Asia, major local partners and subsidiaries or affiliates are based in Indonesia, Malaysia, the Philippines, Singapore, Thailand, and Vietnam,ii whereas TMC's affiliate in Singapore is a procurement centre that serves as regional operational headquarters (OHQ), visualised $\bar{t}$ as

Diagram 6. Structure and Spatial Linkages of TMC's Production Network in Southeast Asia

(Source: Author's assessment referring conceptually to Kuroiwa \& Heng, 2008)

\section{Toyota Value Chains}

With the structure and spatial linkages described above, TMC and its suppliers, local partners, and subsidiaries have endeavoured to add value during preproduction (i.e. RD\&D), production (i.e. logistical procurement and supply of parts and components, manufacturing, and assembly) and post-production (i.e. final products logistics and delivery, sales and marketing, after-sales services) stages. The following diagram offers a smiling curve depiction of processes in the case of TMC's production networks and business operations in Southeast Asia:

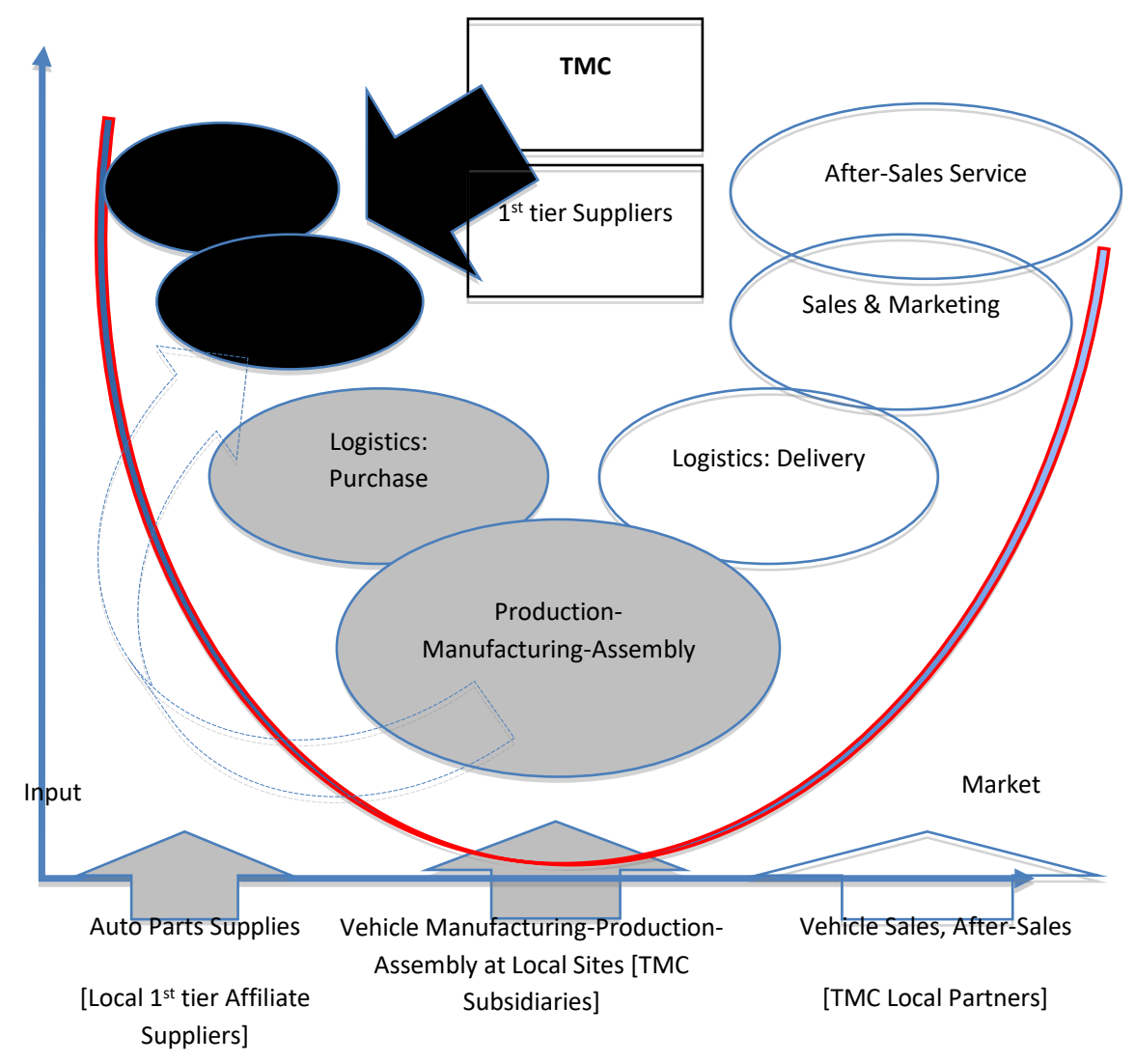


Notes/remarks, legends:

1 Pre-production

$\widehat{1}$ P Post-production
Production

VA Trends

A list of TMC subsidiaries/local partners is available in the endnotes.

Diagram 7. A Smiling Curve of Toyota Value Chains in Southeast Asia (Source: Author's assessment, adapted from Shih, 1996; Gereffi, 2016; Mundambi, 2008; Rabellotti, 2014; Ye et al., 2015)

As shown in Diagram 7, Toyota value chains cover the three main stages of preproduction, production, and post-production. The pre-production stage is occupied mainly by TMC and its first-tier suppliers as it involves capital-intensive RD\&D activities with significant accumulated knowledge, technical know-how, and technology. Several local production sites, however, have facilities for limited and localised RD\&D activities. Such trends (symbolised by a dashed-line moving upwards from production to pre-production in Diagram 7) have been among the highlighted features in TNGA application at local manufacturing sites.

Referring to the above smiley curve, the actual production stage conceptually offers the least value-added compared to pre-production and post-production stages. However, in the case of Toyota, this stage represents a series of core tasks undertaken by a large number of TMC companies, specialised divisions, first tier suppliers, local partners (along with local networks), subsidiaries/affiliates, and lower-tier suppliers. TPS has been at the heart of such long production processes and is the main reference for optimising manufacturing costs, lead time, and production (Just in Time/JIT on pull system, continuous flow processing, takt time). In TPS, therefore, value added is incurred in efforts to reduce unnecessary work/waste (muda), instability and fluctuation (mura), and overload/overburden/overwork (muri) (Takeno, 2017; Tangkas, 2009).

Post-production activities, meanwhile, have been mostly undertaken collaboratively under the Toyota global strategy by TMC, local partners, and subsidiaries/affiliates. This stage covers a wide range of activities, from logistical delivery, marketing and sales of final and after-market products, to after-market services (including advertising and various brand awareness programmes, as well as consumer and public relations). Local partners and subsidiaries/affiliates play a crucial role in formulating, initiating, executing, and more importantly maintaining 
such activities. TMC's lengthy and robust relations have contributed to value being created and captured in this particular stage. The following sub-sections discuss Toyota's value chains from the two main elements: production shifts and upgrading. The sub-section on production shifts explores the movement or transfer of products, parts, and components within TMC's production network and supply chains, while the sub-section on upgrading assesses activities undertaken within the value chains by TMC and its suppliers, local partners, and subsidiaries.

\section{Production Shifts}

Starting its operations as early as the 1960s, in the 1990s TMC outlined its expansion plan for production networks in Southeast Asia through its Toyota IMV project, with its debut products officially launched in 2004. With a current total annual production capacity of more than 1 million units, the Toyota Group's manufacturing activities in the region have the following features:

Table 1. Toyota in Southeast Asia, Production Features

\begin{tabular}{|c|c|c|}
\hline Host & Major Features & Remarks \\
\hline $\begin{array}{l}\text { THAILAND } \\
\text { (THA) }\end{array}$ & $\begin{array}{l}\text { IMV Project: Production of } \\
\text { Hilux pickup trucks and } \\
\text { Fortuner SUVs (Sport Utility } \\
\text { Vehicles) } \\
\text { - Development of a compact car } \\
\text { platform: Production of Yaris } \\
\text { hatchback and Vios sedan } \\
\text { (until 2013) } \\
\text { - Production of Camry and the } \\
\text { mid-level sedan Corolla } \\
\text { Establishment of RD\&D } \\
\text { facility (in 2003) }\end{array}$ & 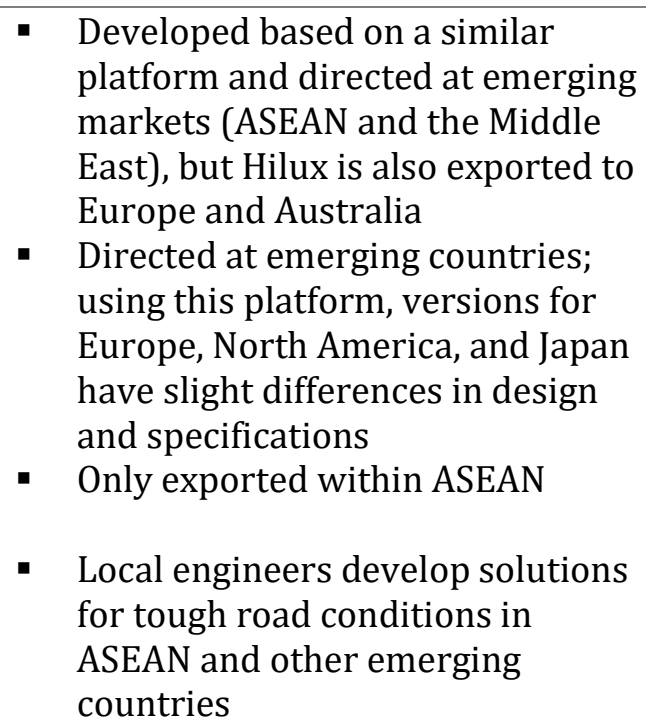 \\
\hline \multirow[t]{2}{*}{$\begin{array}{l}\text { INDONESIA } \\
\text { (IDN) }\end{array}$} & $\begin{array}{l}\text { Under Toyota Brand } \\
\text { - } \quad \text { Production of IMV models: } \\
\quad \text { Fortuner SUV and Innova MPV } \\
\text { - } \quad \text { Production of all Vios models }\end{array}$ & $\begin{array}{l}\text { - Exported within ASEAN and to the } \\
\text { Middle East } \\
\text { - Used to be imported from } \\
\text { Thailand }\end{array}$ \\
\hline & $\begin{array}{l}\text { Under Daihatsu Brand } \\
\text { Production of popular } \\
\text { compact MPV Xenia and its } \\
\text { sister model, Toyota Avanza. }\end{array}$ & $\begin{array}{l}\text { - With the exception of the brand } \\
\text { logo, these two models are } \\
\text { identical; Avanza is exported to } \\
\text { ASEAN, South Africa, and some }\end{array}$ \\
\hline
\end{tabular}




\begin{tabular}{|c|c|c|}
\hline & $\begin{array}{l}\text { Production of compact sedan } \\
\text { Ayla and its sister model } \\
\text { Toyota Agya (since 2013) } \\
\text { - Assembly of Terios SUV and } \\
\text { the rebadged version of } \\
\text { Toyota Rush }\end{array}$ & $\begin{array}{l}\text { countries in the Middle East } \\
\text { These two vehicles are also } \\
\text { identical, and Agya is exported to } \\
\text { the Philippines (from February } \\
\text { 2014); both vehicles conform to } \\
\text { the Indonesian government LCGC } \\
\text { (low cost green car) policy } \\
\text { Daihatsu trails Toyota in terms of } \\
\text { market share, but because it is } \\
\text { part of the Toyota group, Daihatsu } \\
\text { produces and sells its models in } \\
\text { cooperation with Toyota }\end{array}$ \\
\hline $\begin{array}{l}\text { MALAYSIA } \\
\text { (MYS) }\end{array}$ & $\begin{array}{l}\text { Under Daihatsu Brand } \\
\text { - Co-production with Perodua } \\
\text { (Daihatsu rebadged sedan) }\end{array}$ & $\begin{array}{l}\text { - Sold domestically for Malaysian } \\
\text { market }\end{array}$ \\
\hline $\begin{array}{l}\text { PHILIPPINES } \\
\text { (PHI) }\end{array}$ & $\begin{array}{l}\text { - Production of Vios and Innova } \\
\text { MPV }\end{array}$ & $\begin{array}{l}\text { Much smaller scale (than in } \\
\text { Thailand and Indonesia), sold for } \\
\text { domestic market only }\end{array}$ \\
\hline $\begin{array}{l}\text { VIET NAM } \\
\text { (VNM) }\end{array}$ & $\begin{array}{l}\text { CKD assembly for IMV models } \\
\text { and Corolla, Camry, and Vios }\end{array}$ & Mainly for domestic market \\
\hline
\end{tabular}

(Source: Kobayashi, 2014; TMC 2, 2017)

With such production features, Toyota has taken a leading position in both production and market share in key ASEAN countries (except Malaysia, due to the legacy of its "national car" policy). Table 2 offers detailed information on Toyota's production and market shares in ASEAN5 countries (Indonesia, Malaysia, the Philippines, Thailand, and Vietnam).

Table 2. Toyota Production and Market Shares in ASEAN5

\begin{tabular}{|c|c|c|}
\hline Host & Production Share & Market Share \\
\hline THA & $\begin{array}{l}21.5 \% \text { (as of } 2015 \text { ) of total } \\
\text { domestic vehicle production } \\
\text { capacity ( } 3.66 \text { million units) or } \\
\text { actual production ( } 1.92 \text { million } \\
\text { units) [Rank: \#1] }\end{array}$ & $\begin{array}{l}35.2 \% \text { (as of } 2015 \text { ) of total domestic } \\
\text { passenger vehicles sales }(0.299 \\
\text { million units), } 32 \% \text { (as of } 2015 \text { ) of } \\
\text { total domestic commercial vehicles } \\
\text { sales ( } 0.112 \text { million units) [Rank: \#1] }\end{array}$ \\
\hline IDN & $\begin{array}{l}45.6 \% \text { (as of 2016) of total } \\
\text { domestic vehicle production (1.29 } \\
\text { million units) [Rank: \#1] }\end{array}$ & $\begin{array}{l}35 \% \text { (as of 2016) of total domestic } \\
\text { vehicle sales (1.21 million units) } \\
\text { [Rank: \#1] }\end{array}$ \\
\hline MYS & $\begin{array}{l}10.3 \% \text { (as of } 2016 \text { ) of total } \\
\text { domestic vehicle production ( } 0.545 \\
\text { million units) [Rank: \#3, } \\
\text { extrapolated from Natsuda et al., }\end{array}$ & $\begin{array}{l}8.7 \% \text { (as of } 2016 \text { ) of total domestic } \\
\text { passenger vehicles sales }(0.515 \\
\text { million units) [Rank: \#4], } 29.2 \% \text { (as of } \\
\text { 2016) of total domestic commercial }\end{array}$ \\
\hline
\end{tabular}




\begin{tabular}{|c|c|c|}
\hline & 2012] & $\begin{array}{l}\text { vehicles sales ( } 0.065 \text { million units) } \\
\text { [Rank: \#1] }\end{array}$ \\
\hline PHI & $\begin{array}{l}56.1 \% \text { (as of } 2016 \text { ) of total } \\
\text { domestic vehicle production }(0.098 \\
\text { million units) [Rank: \#1] }\end{array}$ & $\begin{array}{l}45.2 \% \text { (as of } 2016) \text { of total domestic } \\
\text { vehicle sales ( } 0.350 \text { million units) } \\
\text { [Rank: \#1] }\end{array}$ \\
\hline VNM & $\begin{array}{l}22 \% \text { (as of } 2016 \text { ) of total domestic } \\
\text { vehicle production ( } 0.236 \text { million } \\
\text { units) [Rank: \#2] }\end{array}$ & $\begin{array}{l}28.14 \% \text { (as of } 2015 \text { ) of total domestic } \\
\text { vehicle sales ( } 0.270 \text { million units) } \\
\text { [Rank: \#1] }\end{array}$ \\
\hline
\end{tabular}

(Source: Yongpisanphob, 2016 for Thailand (THA); GAIKINDO, 2017 for Indonesia (IDN); Natsuda et al., 2012; MAA, 2017; Paultan, 2017 for Malaysia (MYS); TMP, 2017; APEC, 2016; Topgear Philippines, 2016 for the Philippines (PHI); AAF, 2016; Sundjojo, 2016; TMV, 2017 for Vietnam (VNM))

In addition to vehicle production, Toyota subsidiaries/affiliates in Southeast Asia also locally produce various major key automotive parts and components such as engines, propeller shafts, and casting parts (by STM in Thailand); engines, jigs, dies, and various components (by TMMIN in Indonesia); transmission components (by TAP in the Philippines); and engine computer components (by ASSB in Malaysia) (JAMA, 2007; TMMIN, 2017; STM, 2016; Asawachintachit, 2012; Takeno, 2017; Wesley Net ECAT, 2017; Cheewatrakoolpong, Sabhasri \& Bunditwattanawong, 2013 as adapted from Dent, 2008).

Followed typical manufacturing orders and stages (car assembly, engine assembly, large scale casting of engine blocks, parts, and accessories), TMC operations in Southeast Asia have commonly also been preceded by the technical capacity and know-how accumulated at local manufacturing sites, i.e. by ensuring connectedness in the supply chains and the levelling of technological application among these sites. The Toyota IMV Project, hence, makes use of such accumulation and adds on a common platform for vehicle types specifically designed both for local (regional) and global markets (Takeno, 2017). The following diagram depicts the platform of the Toyota IMV Project applied in Southeast Asia: 


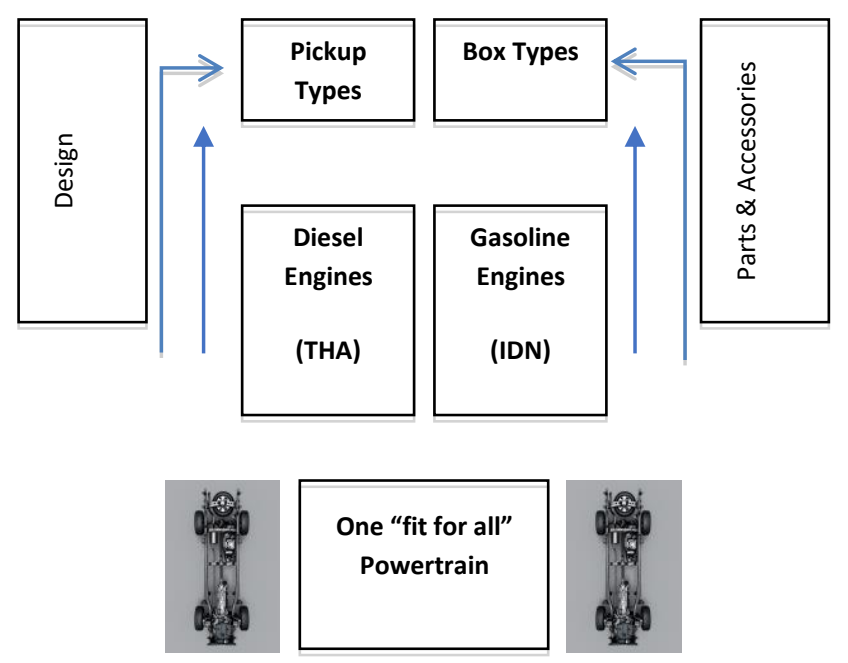

\begin{tabular}{|c|c|}
\hline TNGA Global Platform & ASEAN IMV Platform \\
New front-wheel- drive & $\begin{array}{c}\text { Enhanced flexibility in the } \\
\text { platform for B, C and D- } \\
\text { segment programs; } \\
\text { Major modular } \\
\text { styling: broader range of } \\
\text { vertrain, braking \& } \\
\text { steering components are } \\
\text { shared across platforms }\end{array}$ \\
Scale \& purpose \\
\hline
\end{tabular}

Remarks: (1) The image is a Toyota Fortuner powertrain, one MPV type based on IMV platform; (2) Toyota car segment programmes are in line with the Commission of the European Union's classification, with B referring to "small cars" (normal or small-size cars, e.g. Sienta, Probox, Vios, Etios, Vitz, Yaris, Starlet), C refers to "medium cars" (universal or small family cars, e.g. Corolla, Prius, Matrix), and D refers to "large cars" (larger family cars with a sufficient comfort level for rear passengers and improved driveability, e.g. Premio, Lexus IS). Meanwhile, the Toyota Fortuner is categorised J: "sport utility cars" or SUVs.

Diagram 8. Platform for Toyota IMV Project in Southeast Asia (Source: interpreted, adapted from \& based on TMC 1, 2017; Seng, 2016; and Takeno, 2017)

The movement and transfer of major parts and components follow a pattern that is characterised by manufacturing specialisation; Toyota's Thai facilities concentrate on the production of diesel engines, its Indonesian facilities focus on gasoline engines, its Filipino facilities concentrate on transmission and constant velocity joints, and its Malaysian facilities focus on engine computers. As a result, major parts and components under the IMV project that were transferred between Toyota Thailand and Toyota Indonesia have shifted as two-way traffic has become increasingly complementary. The IMV platform has been applied for products commonly manufactured both in Thailand (TMT) and Indonesia (TMMIN), i.e. Innova 
and Fortuner (MPVs) and Yaris and Vios (passenger cars). Particular platforms, thus, determine specific types of components and parts related to those products and their transfer between subsidiaries. With other vehicle types manufactured under the same platform, parts and components are also transferred correspondingly.

Diagram 9 illustrates the part and component transfers under the Toyota IMV platform in Southeast Asia and surrounding countries:

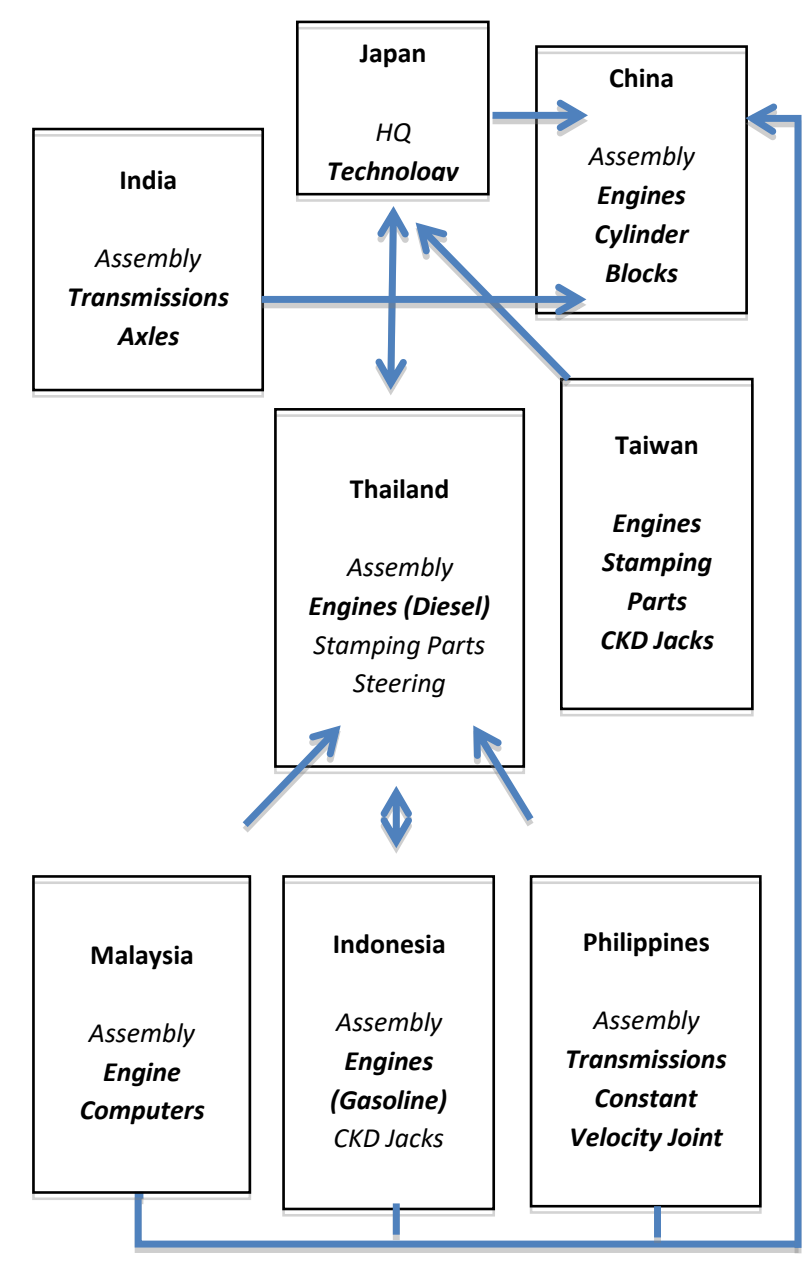

Note: (1) The highlighted (bold) activity in each box signifies each host country/host economy's specialisation in the production network at current condition (2017); (2) lines/arrows indicate the movement and transfer direction of components and parts.

Diagram 9: Part and Component Transfers under the Toyota IMV Project in Southeast Asia and its Surroundings

(Source: Cheewatrakoolpong, Sabhasri \& Bunditwattanawong, 2013; as adapted from Dent, 2008; FOURIN 2015 as quoted in JETRO, 2017; and Takeno, 2017)

With regards to procurement logistics and product delivery, Toyota Motor Asia Pacific Pte Ltd (TMAP-MS) (formerly known as Toyota Motor Management Service 
Singapore Pte Ltd or TMSS) has been taken the role of Toyota's OHQ in the region. It plays a pivotal role by serving as a processing and procurement centre for major parts and components transferred among Toyota's subsidiaries in Southeast Asia. Diagram 10 shows the logistical processes and indicative volume of component and part transfers among Toyota subsidiaries in the region. Under such processes, delivery costs and other logistical costs are optimised by preventing double or multiple cost incurrences among subsidiaries. It ensures that the volume of certain outbound shipments is the same as inbound ones, both to and from Singapore. Shipments of diesel engines and other parts and components from Toyota Thailand (TMT) to other subsidiaries, for example, are the same volume as shipments of other components and parts from other subsidiaries. As a central logistical and procurement centre, TMAP-MS covers not only delivery products among Toyota Southeast Asian subsidiaries, but also between Southeast Asia and Japan, Taiwan, China, and sometimes India (Takeno, 2017).

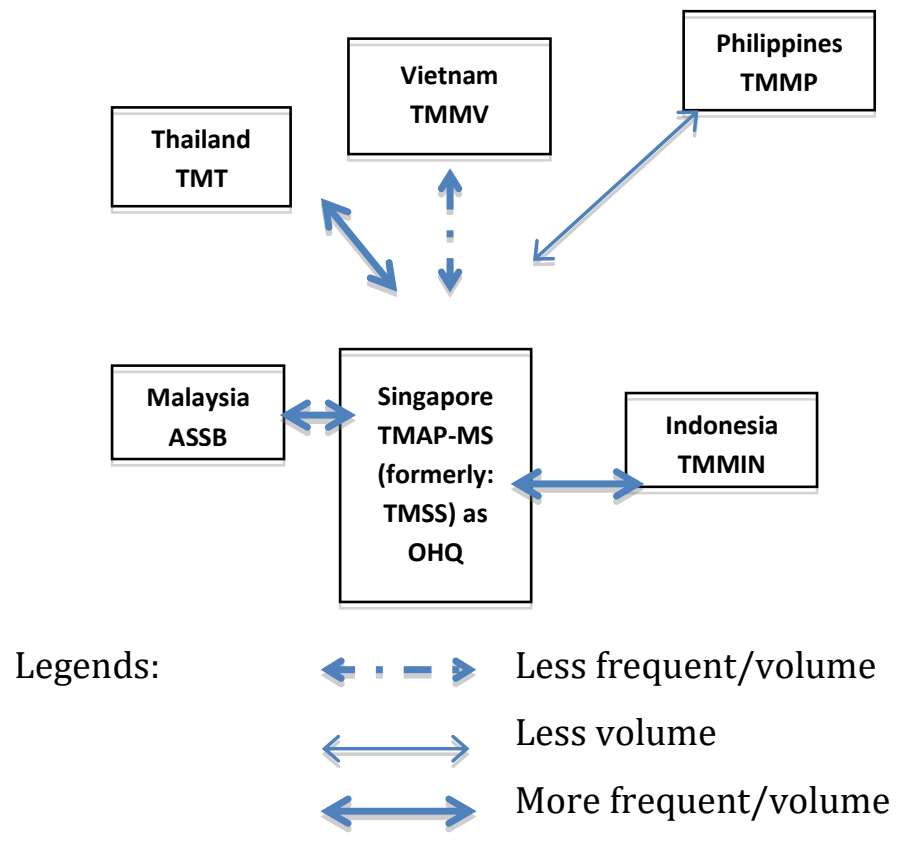

Diagram 10. Logistics Flow among Toyota Subsidiaries in Southeast Asia (Source: Author's assessment, based on Takeno, 2017)

\section{Upgrading}

In Southeast Asia, TMC's overall upgrading strategy has been undertaken by and applied mainly within the domain of subsidiary companies, i.e. Toyota Motor Asia Pacific Pte Ltd (TMAP). Initially founded as TMSS in Singapore (May 1990), 
TMAP currently has two affiliate companies, i.e. TMAP-MS (which replaced TMSS in April 2001) and Toyota Motor Asia Pacific Engineering \& Manufacturing Co. Ltd. (TMAP-EM) located and based in Bangkok (which changed its name to Toyota Daihatsu Engineering \& Manufacturing [TDEM] on 3 April 2017). TMAP's organisational structure consists of a management team led by a chief executive officer who co-worked with a chief technical officer based in TMAP-MS in Singapore and aided by a deputy chief executive officer based in TMAP-EM (or now TDEM) in Bangkok. The management covers their work and responsible for two main areas: Asia (to which Southeast Asia belongs) and the Middle East and North Africa (including Central Asia) (TMAP, 2016; TDEM, 2017; Bloomberg, 2017; TMC 1, 2017).

Since 2001, i.e. following its organisational restructuring, TMAP has expanded its functions to cover not only operational processing and procurement, but also to support the application of TPS at local manufacturing sites, i.e. to support the design, development, and manufacturing of certain localised vehicle types. Fields of support include basic TPS management, production-related aspects, RD\&D, and sales. These functions have been expanded gradually and follow these sequential stages overtime:

1. Modest sales function (1997-2000): logistics and commercial delivery of products are the main activity features (under TMSS)

2. Advanced sales function, involving assessment of product pricing, supply and demand, and customer service (since 2001, i.e. the restructuring of TMSS and TMAP-MS)

3. On top of those modest and advanced sales functions, RD\&D activity commenced (in 2003-4) with the establishment of technical centres that became the embryo of TMAP-EM in Bangkok (founded in April 2007)

4. Full operation of TMAP-EM marked the start of production-related functions, i.e. in manufacturing techniques and procurement of parts and component, supply chains (since 2007), production support (since 2008) and planning (since 2009), vehicle project planning (since 2012), and "Z" feature support for the development of four-piston engine vehicles (since 2013-14).

In RD\&D, undertaken mainly by TDEM's Technical Centre (formerly TMAPEM), the main activity is vehicle engineering and evaluation (in 2003, still under TTCAP [Toyota Technical Center Asia Pacific] in Australia, but under TMAP- 
EM/TDEM since 2007). Vehicle parts engineered and evaluated in the technical centre include Vigo C-Access Door (2008), Corolla CNG (2010), Vigo CNG (2012) and REVO (2015). Diagram 11 shows the flow of TC RD\&D processes. It also demonstrates the technical capabilities of the centre. Upon assessment on the market and funding, the first stage is product planning, which involves managerial as well as technical expertise. The second stage is design, i.e. transforming product plans into product prototypes using detailed engineering drawings that meet technical aspects and other considerations. The third stage is evaluation, i.e. a postdesign (and post-production) activity for evaluating the performance or results of designed (or manufactured) products. The fourth stage is localisation, where local manufacturing sites' capabilities for optimum usage of local parts and components, engineers, engineering techniques, and other managerial tasks.

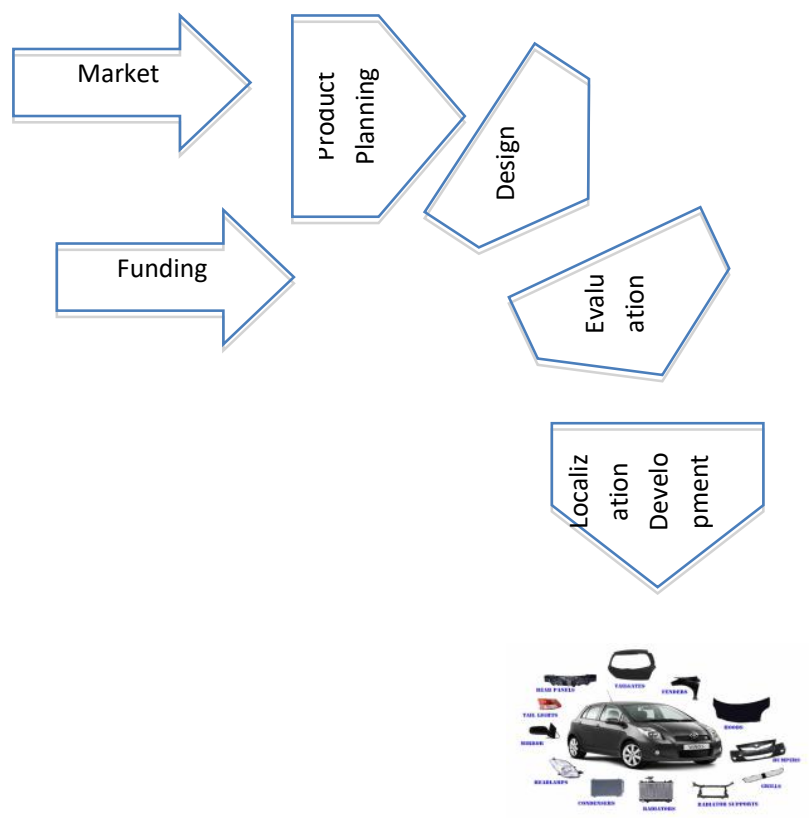

Diagram 11. RD\&D Technical Capabilities and Flows at the TMAP/TDEM Technical Centre

(Source: TMAP, 2016)

Referring to TMAP's business range and the wide geographical coverage of its activities (especially RD\&D, under its Technical Centre), TMC's upgrading efforts in its Southeast Asian operations have focused mostly on "functional" and "interchains" upgrading. iii These efforts co-exist with TMC's continuing endeavours to add value through the "product" and "process" upgrading embodied in the TPS/Toyota Way -kaizen (continuous improvement), hansei (relentless reflection), genchi 
genbutsu (solving problems by seeing what is really going on). These two-layered upgrading efforts (as shown in Diagram 12) feature interconnectedness between TMC, its first-tier suppliers, local partners and regional subsidiaries during preproduction, production, and post-production activities.

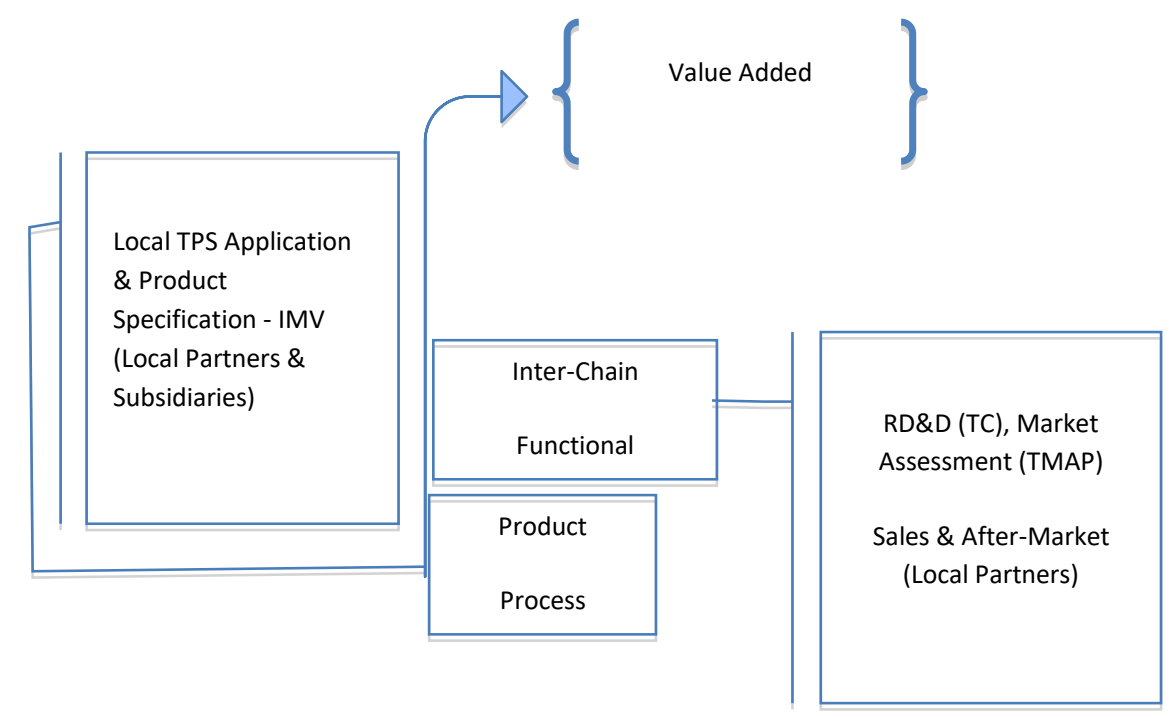

Diagram 12. TMC Two-layered Upgrading in Southeast Asia (Source: author's assessment)

Table 3 recapitulates details of activities undertaken by TMC and its production network in Southeast Asia that indicate upgrading efforts along its value chains. The assessment offers micro-level analysis of the upgrading strategy and other related measures used by the lead firm (TMC or Toyota Group), its first-tier suppliers, local partners, and subsidiaries/affiliates in the region.

Table 3. Toyota Upgrading Activities in Southeast Asia

\begin{tabular}{|c|c|c|}
\hline & Features & Remarks \\
\hline 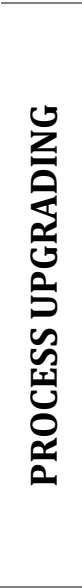 & 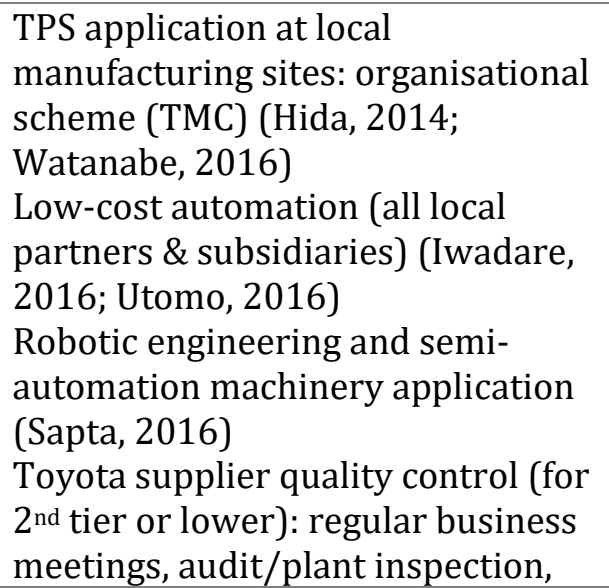 & $\begin{array}{l}\text { Official organisational scheme is conducted } \\
\text { via self-reliance division or development } \\
\text { department to ensure quality and a } \\
\text { standardised process of manufacturing. } \\
\text { Flexibility in adapting to local } \\
\text { manufacturing conditions and technology } \\
\text { gives them the option of applying and } \\
\text { utilising existing facilities with limited } \\
\text { adjustment (case on Toyota Kijang) } \\
\text { Full (robotic) and semi-automation are } \\
\text { adopted when market demands require } \\
\text { rapid expansion of facilities (as in the case } \\
\text { of new plants in Indonesia and Thailand) }\end{array}$ \\
\hline
\end{tabular}


regular vocational training (Mizuta, 2016; Prasetiyani, 2016)
Solid relations with suppliers are essential for full application of TPS at local manufacturing sites

\begin{tabular}{|c|c|c|}
\hline 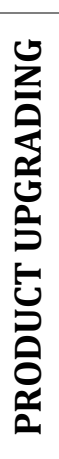 & $\begin{array}{l}\text { ASEAN IMV Project Platform } \\
\text { Powertrain: } 1 \text { Ton Pickup Trucks, } \\
\text { Small MPVs, LCGC (TMC, STM, } \\
\text { TMMIN) (TMC 1, 2017; Takeno, } \\
\text { 2017) } \\
\text { Local consumer-driven products } \\
\text { (Watanabe, 2016) }\end{array}$ & $\begin{array}{l}\text { Despite using shared platform and } \\
\text { powertrain in IMV models, product variety } \\
\text { and specification must be considered to add } \\
\text { product value } \\
\text { Specific and unique additional features are } \\
\text { installed in IMVs (e.g. mini refrigerators for } \\
\text { Thai consumers, cup holders for US } \\
\text { consumers in one-ton Pickup trucks) }\end{array}$ \\
\hline 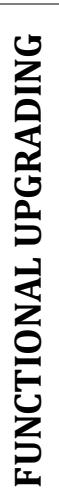 & $\begin{array}{l}\text { RD\&D and Market Assessment (TC } \\
\text { TMAP) } \\
\text { Local R\&D centres (TDEM in Thailand } \\
\text { and ADM in Indonesia): aim to } \\
\text { develop small IMVs in collaboration } \\
\text { with Daihatsu (TDEM, 2017; Hayato, } \\
\text { 2016) } \\
\text { In house R\&D engineering centre (1st } \\
\text { tier Suppliers, Case of Denso } \\
\text { Corporation) }\end{array}$ & $\begin{array}{l}\text { TC TMAP takes a leading role in } \\
\text { engineering development and market } \\
\text { intelligence functions by regularly linking } \\
\text { its work and business with those of other } \\
\text { subsidiaries/affiliates, e.g. TMMIN regularly } \\
\text { consult with TC TMAP for RD\&D aspects of } \\
\text { production (Sapta, 2016) } \\
\text { ADM collaborates with an automotive } \\
\text { research centre at Binus University }\end{array}$ \\
\hline 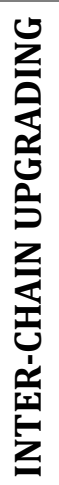 & $\begin{array}{l}\text { Sales, Marketing, and After-Market } \\
\text { Services (TMC, TMAP and Local } \\
\text { Partners/TAM, TMT, TMP, TMV) } \\
\text { Active participation and engagement } \\
\text { in activities, programmes, and events } \\
\text { organised by local automobile } \\
\text { assemblers or OEM associations, and } \\
\text { automotive research } \\
\text { institutes/centres (Jirathiyut, 2016) }\end{array}$ & $\begin{array}{l}\text { Local partners are actively engaged in } \\
\text { brand awareness campaigns and connect to } \\
\text { local users and consumers through various } \\
\text { Toyota Club activity (TAM, 2017; TMMIN, } \\
\text { 2017; TMT, 2017; TMP, 2017; TMV, 2017) } \\
\text { TMC local partners and subsidiaries } \\
\text { regularly participate in major events, } \\
\text { including automotive shows and annual } \\
\text { conferences. }\end{array}$ \\
\hline
\end{tabular}

(Source: Author's assessment)

\section{Conclusion}

The production shifts and upgrading undertaken within Toyota's value chains in Southeast Asia have offered insights on regional economic integration. Toyota's ASEAN IMV project offers evidence that production shifts brings about the localisation of production through gradual accumulation of local manufacturing and production capabilities as well as engineering expertise. On the part of its local partners and subsidiaries, TMC has engaged in an overall upgrading strategy that covers upstream, midstream, and downstream business activities. This particular phenomenon (characterised by flexible movement in two essential production 
factors: capital and goods) confirms the elementary success of AEC. However, free capital movement in the form of direct foreign investment does not always equate to successfully supporting local industrial development. Beyond the AEC's elementary success, TMC's engagement and practical experiences in RD\&D have upgraded to link and pool regional engineering expertise within its value chains. Despite its limited coverage, it exemplifies freer trade in services in the region (a sector underachieving in the current application of the AEC scheme).

\section{Acknowledgements}

The author would like to kindly express his sincere gratitude to Professor Hideaki Ohta, Ph.D. (the author's chief dissertation supervisor) who has fully supported this research, eagerly offered insightful inputs and comments, and keenly shared resources and networks. The paper is part of the author's doctoral dissertation titled "Regional Value Chains and the Japanese Automotive Production Network in Southeast Asia" at the Graduate School of International Relations, Ritsumeikan University. Portions of funding (i.e. doctoral programme scholarship and fieldwork activity) have been provided through the BPPLN DIKTI (Indonesian Ministry of Research, Technology \& Higher Education, Directorate General of Resources for Science, Technology and Higher Education) Scholarship Scheme and Ritsumeikan University's Kokusaiteki Research Fund.

\section{References}

Ando, M., \& Kimura, F. (2009). Fragmentation in East Asia: Further Evidence. ERIA Discussion Paper Series. Jakarta: ERIA.

Asawachintachit, D. (2012, 21 September). Thailand: Automotive Hub of Asia. Bangkok, Thailand: BOI Thailand.

ASEAN Automotive Federation (AAF). (2016). AAF Statistics: Sales 2016. Retrieved from http://www.asean-autofed.com/files/AAF_Statistics_2016.pdf (30 August 2017).

ASEAN Secretariat and World Bank. (2015). ASEAN Services Integration Report 2015. ASEAN Secretariat and World Bank, ASEAN Integration Monitoring Office (AIMO), and World Bank. East Asia and Pacific Region. Jakarta and Washington DC: ASEAN Secretariat and World Bank. 
ASEAN Secretariat. (2015). ASEAN Integration Report 2015. ASEAN Secretariat, ASEAN Integration Monitoring Office (AIMO), and Public Outreach and Civil Society Division (POCS). Jakarta: ASEAN Secretariat.

Asia Pacific Economic Cooperation (APEC). (2016). Philippines - Peer Review: Automotive Market, Production, Trade and Policy. APEC, APEC Peru 2016. Manila: Department of Trade and Industry of the Philippines.

Banga, R. (2013, May). Measuring Value in Global Value Chains. UNCTAD Regional Value Chains, Background Paper No. RVC-8.

Bloomberg. (2017). Distributors: Company Overview of TMAP. Retrieved from https://www.bloomberg.com/research/stocks/private/snapshot.asp?privcapI $d=22510572$ (30 August 2017).

Cheewatrakoolpong, K., Sabhasri, C., \& Bunditwattanawong, N. (2013, February). Impact of the ASEAN Economic Community on ASEAN Production Networks. ADBI Working Paper Series (No. 409).

Cusumano, M. A. (1985). The Japanese Automobile Industry: Technology and Management at Nissan and Toyota. Cambridge and London, Massachusetts, USA and UK: The Council on East Asian Studies, Harvard University.

Dent, C. (2008). China, Japan and Regional Leadership in East Asian. Cheltenham, UK: Edward Elgar Publishing.

GAIKINDO. (2017). Indonesian Automobile Industry Data. Retrieved from https://files.gaikindo.or.id/my_files/ (30 August 2017).

Gereffi, G. (2016, 17 June). Global Value Chains and Development: Concepts and Methodologies. Retrieved from https://www.slideshare.net/DukeCGGC/globalvalue-chains-and-development-concepts-and-methodologies (30 August 2017). . (1995). Global Production Systems and Third World Development. In B. Stallings, \& B. Stallings (eds.), Global Change, Regional Response: The New International Context of Development. New York: Cambridge University Press.

Hayato, T. (2016, 10 November). Interview Meeting Minutes. Jakarta: HIDA Indonesia.

Hida, K. (2014, 9 December). Interview Meeting Minutes. Toyota City: TMC.

Humphrey, J., \& Schmitz, H. (2002). How Does Insertion in Global Value Chains Affect Upgrading in Industrial Clusters? Regional Studies, 36, 1017-1027. (2000). Governance and Upgrading: Linking Industrial Cluster and Global 
Value Chain Research. IDS Working Paper 120.

Iwadare, Y. (2016, 19 August). Interview Meeting Minutes. Tokyo: Nomura Research Institute.

Japan Automobile Manufacturers Association (JAMA). (2007). Hand in Hand: Partnership in the Auto Industry between Japan and ASEAN. Retrieved from http://www.jamaenglish.jp/asia/publications/pamphlets/2007/hand_in_hand_2007.pdf August 2017).

JETRO. (2017, March). 2016 Annual Report on Asian Automotive Industry Competitiveness (Country Case Studies: Vietnam, Myanmar, Thailand and Indonesia). Tokyo: JETRO.

Jirathiyut, V. (2016, 16 October). Interview Meeting Minutes. Bangkok: Thai Automotive Institute.

Kimura, F. (2007). The Mechanics of Production Networks in Southeast Asia: The Fragmentation Theory Approach. Center for Economic Institutions Working Paper Series. Tokyo: Center for Economic Institutions, Institute of Economic Research, Hitotsubashi University.

Kuroiwa, I., \& Heng, T. M. (2008). Production Networks and Industrial Clusters: Integrating Economies in Southeast Asia. Singapore: IDE JETRO and ISEAS.

Liker, J. K. (2004). The Toyota Way: 14 Management Principles for the World's Greatest Manufacturer. New York: McGraw-Hill.

Liker, J. K., \& Hoseus, M. (2008). Toyota Culture: The Heart and Soul of the Toyota Way. New York: McGraw-Hill.

Malaysia Automotive Association (MAA). (2017). Malaysia Automotive Info: Summary of Sales and Production Data. Retrieved from http://www.maa.org.my/info_summary.html (30 August 2017).

Mizuta, Y. (2016, 8 January). Interview Meeting Minutes. Inuyama: Aoyama Seisakusho Japan (ASJ).

Monden, Y. (2012). Toyota Production System: An Integrated Approach to Just-InTime. Boca Raton, Florida: CRC Press, Taylor \& Francis Group.

Mundambi, R. (2008). Location, Control, and Innovation in Knowledge-Intensive Industries. Journal of Economic Geography, 8(5), 699-725.

Natsuda, K., et al. (2012, 24 April). Globalisation and the Malaysian Automotive 
Industry: Industrial Nationalism, Liberalisation, and the Role of Japan. RCAPS Working Paper Series (RWP-12002).

Ohno, T. (1988). Toyota Production System: Beyond Large-Scale Production. United States: Book Crafters.

Paultan. (2017). Vehicle Sales Performance in Malaysia, 2016 vs 2015 - A Look at Last Year's Biggest Winners and Losers. Retrieved from https://paultan.org/2017/01/19/vehicle-sales-performance-in-malaysia2016-vs-2015-a-look-at-last-years-biggest-winners-and-losers/ (30 August 2017).

Prasetiyani, D. (2016, 4 February). Interview Meeting Minutes. Karawang: Automotive Fasteners Aoyama Indonesia (AFD).

Rabelloti, R. (2014, 20 March). Upgrading in Global Value Chains: The Role of Knowledge and Technological Capabilities. Presentation Materials. UNCTAD.

Sapta, A. (2016, 2 February). Interview Meeting Minutes. Jakarta: PT TMMIN.

Seng, M. (2016, 26 April). Trends and Technology Impacting the North American Automotive Aftermarket. from http://slideplayer.com/slide/10248245/ (30 August 2017).

Shih, S. (1996). Me-Too is Not My Style: Challenge Difficulties, Break through Bottlenecks, Create Values. Taipei: The Acer Foundation.

Siam Toyota Motor (STM). (2017). Siam Toyota Motor. Retrieved from http://www.siamtoyota.co.th/index.aspx (30 August 2017).

Soejachmoen, M. P. (2016). Globalization of the Automotive Industry: Is Indonesia Missing Out? Asian Economic Papers 15(1).

Sundjojo, D. D. (2016, 16 March). Vietnam is the New Hope for Automotive Industry. Retrieved from https://www.linkedin.com/pulse/vietnam-new-hopeautomotive-industry-daniel-doni-sundjojo (30 August 2017).

Takeno, T. (2017, 13 June). Interview Meeting Minutes. Nagoya: Nagoya Institute of Technology.

Topgear Philippines. (2016). Toyota PH's 2016 Sales by Numbers. Retrieved from http://www.topgear.com.ph/news/industry-news/toyota-ph-s-2016-sales-bythe-numbers-a00012-20170124 (30 August 2017).

Toyota Daihatsu Engineering and Manufacturing (TDEM). (2017). Update News and Event. Retrieved from http://www.tdem.toyota-asia.com/update- 
0000162.html (30 August 2017).

Toyota Motor Asia Pacific (TMAP). (2016, 19 December). TMAP Company Profile. Singapore \& Bangkok: TMAP-MS and TMAP-EM.

Toyota Motor Corporation (TMC) 1. (2017). 75 Years of Toyota. Retrieved from http://www.toyotaglobal.com/company/history_of_toyota/75years/index.htm 1 (30 August 2017).

Toyota Motor Corporation (TMC) 2. (2017). Toyota Global. Retrieved from http://www.toyota-global.com/ (30 August 2017).

Toyota Motor Manufacturing Indonesia (TMMIN). (2017). Toyota Indonesia. Retrieved from http://www.toyotaindonesiamanufacturing.co.id/ (30 August 2017).

Toyota Motor Philippines (TMP). (2017). Toyota Philippines. Retrieved from http://www.toyota.com.ph/ (30 August 2017).

Toyota Motor Vietnam (TMV). (2017). Toyota Vietnam. Retrieved from http://www.toyotavn.com.vn/en/ (30 August 2017).

Utomo, B.B. (2016, 8 November). Interview Meeting Minutes. Jakarta: Toyota Institute/POLMAN Astra.

Watanabe, T. (2016, 8 January). Interview Meeting Minutes. Nagoya: Chukyo University.

Wesley Net ECAT. (2017). Malaysia Automotive Catalogue. Retrieved from http://www.patersonmedia.com/malaysia/japanindustry2.php?industryid=38 (30 August 2017).

Womack, J. P., Jones, D. T., \& Roos, D. (1990). The Machine that Changed the World: The Story of Lean Production - Toyota's Secret Weapon in the Global Car Wars that is Revolutionizing World Industry. New York, London, Toronto, Sydney: Free Press.

Ye, M., et al. (2015, 27 August). Measuring Smile Curves in Global Value Chains. IDE Discussion Paper (530).

Yongpisanphob, W. (2016, July). Thailand Industry Outlook 2016-18: Automobile Industry. $\quad$ Retrieved from https://www.krungsri.com/bank/getmedia/48d60f2f-eca7-4386-bd381a5b6bc4a3e5/IO_Automobile_2016_EN.aspx (30 August 2017). 


\section{Endnotes}

\footnotetext{
i Under the AEC (which was formally established on December 31st 2015), the integration scheme has been developed under the AEC Blueprint 2025, which envisions an economic community that is highly integrated and cohesive; competitive, innovative and dynamic; with includes enhanced connectivity and sectoral cooperation; more resilient, inclusive, and people-oriented, people-centred service; and is integrated with the global economy (ASEAN Economic Integration Brief, June 2017). In regards to the region's growing importance of production networks, ASEAN has reiterated the importance of enhanced participation in global supply networks as a result of ASEAN's solid attachment to global value chains (GVCs), as evidenced in its manufacturing (including automotive) sectors. ASEAN member states need to focus increasingly on the availability, quality, and efficiency of standards and conformity assessment infrastructure, as well as in ensuring compliance capacity building among by the smaller economic actors - which are the main prerequisite for s of enhanced participation in GVCs (ASEAN Secretariate, 2015).

ii The list is as follows: PT Toyota Astra Motor (TAM), PT Toyota Motor Manufacturing Indonesia (TMMIN), PT Astra Daihatsu Motor (ADM), PT Sugity Creatives (PTSC), and PT Hino Motors Manufacturing Indonesia (HMMI) in Indonesia; United Motor Works Sdn Bhd (UMW), UMW Toyota Motor Sdn Bhd (UMWT), and Assembly Services Sdn Bhd (ASSB) in Malaysia; Toyota Motor Thailand Co Ltd (TMT), Siam Toyota Manufacturing Co Ltd (STM), and Toyota Auto Works Co Ltd (TAW) in Thailand; Toyota Motor Philippines Corporation (TMP) and Toyota Autoparts Philippines Incorporated (TAP) in the Philippines; and Toyota Motor Vietnam Co Ltd (TMV) in Vietnam.

iii This upgrading typology (process, product, functional and inter-chain) is based on Humphrey and Schmitz (2002) where such process refers to efforts (by firms and other related stakeholders in the value chains) to add value by upgrading production processes; product upgrading signifies the upgraded product quality, performance, and variety of product; functional upgrading focuses on acquiring new functions and skills, and changing mix of activities balance; and inter-chain upgrading emphasizes on the creation and capturing of multi-diverse functions and skills. Process upgrading is typically undertaken in the upstream business activity, while inter-chain upgrading is generally on in its downstream side.
} 